\title{
Chemical composition of healthy and infected leaves by Forda riccobonii and Geoica swirskii of Pistacia atlantica Desf. collected from Maaziz region in Morocco
}

\author{
Hazim Harouak ${ }^{1}$, Jamal Ibijbijen ${ }^{1}$, Touria Zair ${ }^{2}$ and Laila Nassiri ${ }^{1}$ \\ ${ }^{1}$ Soil Microbiology and Environment Unit, Faculty of Sciences, Moulay Ismail University of Meknes, 50000 , \\ Morocco \\ ${ }^{2}$ Laboratory of Chemistry of Bioactive Molecules and Environment, Faculty of Sciences, Moulay Ismail \\ University of Meknes, 50 000, Morocco
}

\begin{abstract}
The Atlas Pistachio, Pistacia atlantica Desf., from the family of Anacardiaceae is a widespread species in Morocco and widely present in traditional pharmacopoeia ${ }^{1}$. This species is frequently infected by Forda riccobonii and Geoica swirskii that are foliar galls-inducing aphids.
\end{abstract}

This study aimed to compare the chemical composition of essential oils (EO) of the infected and healthy leaves of Pistacia atlantica. The extraction of essential oils was performed by hydro-distillation using Clevenger, phytochemical screening was realized by revelations tests, and chemical composition was identified by gas chromatography coupled with mass spectrometry (GC-MS).

Phytochemical analysis showed the presence of some biologically active chemical compounds such as tannins, flavonoids, sterols and triterpenes. The infected leaves were richer in tannins than healthy ones, especially in gallic tannins.

Also, the results revealed that the EO yield of leaves with galls was higher $(0.71 \%)$ than that of healthy ones $(0.11 \%)$; also, the first type of leaves was predominated by $\alpha$-Pinene $(19.76 \%)$ followed by Terpinen-4-ol, Spathulenol and Sabinene with percentages of $11.94 \%, 8.90 \%$ and $7.63 \%$, respectively. Whereas, healthy leaves were predominated by $\alpha$-Amorphene $(15.05 \%)$ followed by Terpinen-4-ol, Spathulenol and $\alpha$-Muurolene with percentages of $7.17 \%, 6.46 \%$ and $6.20 \%$, respectively.

So, we arrived to conclude that infected leaves have a higher level of monoterpenes hydrocarbon than healthy ones that contain interesting molecules useful in different domains, especially in the health field.

Keywords: Pistacia atlantica Desf.; Leaves; Galls, Essentia1 Oil; Phytochemistry; Chemical composition.

\section{Introduction}

The Atlas Pistachio, Pistacia atlantica Desf., from the family of Anacardiaceae and known under the vernacular name "Betoum" or "Btem" 1. It extends spontaneously, from the margins of the Sahara to the plains, low and medium mountains, rarely in pure stands, often in mixture with Thuya «Tetraclinis articulata (Vahl) Masters ${ }^{2}$, in arid bioclimate, semiarid mild, semi-arid cold and subhumid ${ }^{1}$.

Although three other pistachios meet in Morocco, $P$. terebinthus L. «Ij », P. lentiscus $\mathrm{L}$. «Drou» in the wild state and P.vera $\mathrm{L}$. « edible pistachios » in culture $^{1 \text {, }}$. only Atlas pistachio is infected by Forda riccobonii and Geoica swirskii aphids that cause leaf galls.

According to Álvarez and al. (2009) ${ }^{4}$, galls develop

*Corresponding author: Hazim Harouak

Email address: hazim.harouak@gmail.com

DOI: http://dx.doi.org/10.13171/mjc01912041066hh on plants in response to an induction caused by several organisms: microorganisms, nematodes and mites. Also, there are more than 15,000 species of gallic insects. The galls can be found on many organs of the host plant, and a specific organ of the plant can support different types of galls. In the Pistacia genus, we find two subfamilies of insect inducing gall formation: Pemphiginae and Fordinea.

Generally when a plant receives an external attack will have morphological transformations ${ }^{5}$, After the leaf injury at the tea tree (Melaleuca alternifolia Cheel.) the chemical composition of gasoline is also affected in all leaves irrespective of the initial gasoline composition. Some terpenes do increase their concentration ${ }^{6}$.

In this context, the evaluation of the variation in the chemical composition of infected leaves and healthy

Received September 5, 2019

Accepted October 27, 2019

Published December 4, 2019 
ones of Pistacia atlantica Desf. essential oils has been the main objective of the present work.

\section{Materials and methods}

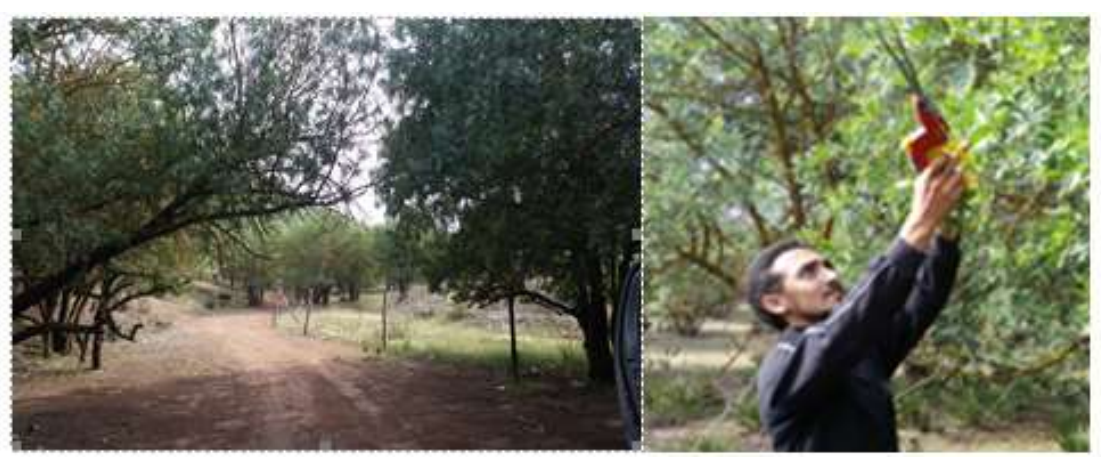

\subsection{Harvest location}

Maaziz (Figure 1) is a rural Moroccan town located in Rabat-Salé-Kenitra region about $35 \mathrm{~km}$ west from Khemisset city via N6 R404 road.

Figure 1. Harvest location area (Maaziz region); $33^{\circ} 38^{\prime} 44.6^{\prime \prime} \mathbf{N} 6^{\circ} 17^{\prime} 58.9^{\prime \prime} \mathrm{W}$

\subsection{Plant material}

The Atlas Pistachio, Pistacia atlantica Desf. (Herbarium specimen: 1810/IS/ $\mathbf{N}^{\circ} 38$ ), is a tree can reach up to $20 \mathrm{~m}$ in high, with a well-individualized trunk ${ }^{7}$. Leaves, imparipinnate with finely winged rachis, are composed of 7-9 broad leaflets, soft, glabrous and deciduous in autumn ${ }^{1}$. The species is dioecious, some monoecious feet have been observed in eastern part of Morocco in Debdou region ${ }^{8}$, however, no hermaphroditism was observed ${ }^{8}$. the inflorescence is a compound cluster, with apetalous flowers; flowering takes place in the spring-summer and the fruit is a little fleshy drupe, bluish when ripe ${ }^{1}$, commonly called Goddime or Tikouaouche and often consumed by residents ${ }^{8}$.

The harvest of Atlas Pistachio was carried out on May 03, 2019 in the Maaziz region. The individuals from whom the leaf samples were taken were randomly selected; each time the healthy leaves were carefully separated from those bearing galls.

We took two samples: healthy leaves, leaves infected, the samples were dried in the shade for about 15 days.

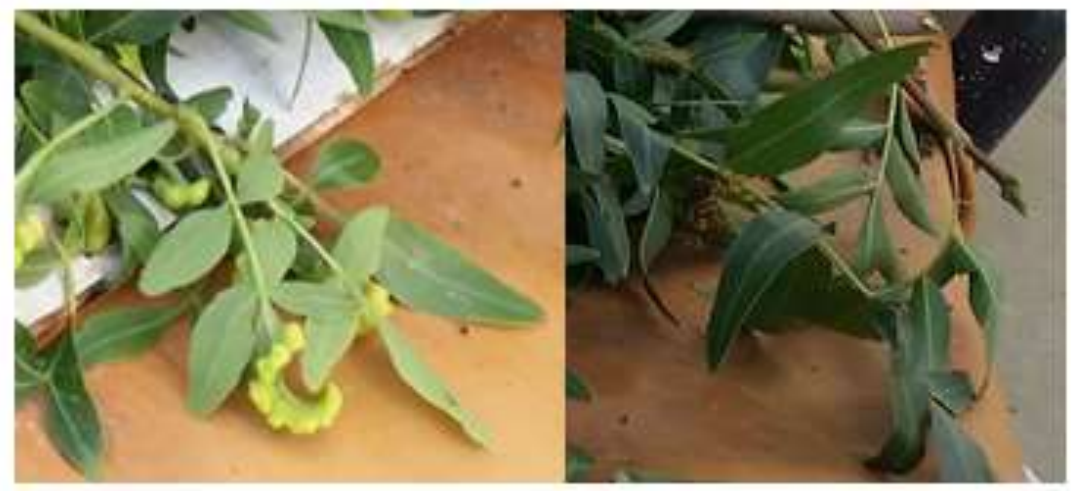

Figure 2. a-Leaves infested by aphids (Photo by HAROUAK, 2019); b-Healthy leaves of Pistacia atlantica Desf.

\subsection{Essential oil extraction of Pistacia atlantica} Desf.

Healthy or infected leaves of Atlas Pistachio were immersed in a 2-liter balloon equipped with a Clevenger type apparatus and a ballon cooler. This mixture was boiled for three hours, using a balloon heater to produce the steam that brings the Essential Oils, the steam produced condenses through a refrigerant. The condensates $(\mathrm{EO}+$ Water $)$ were separated by decantation, then dried over Magnesium sulphate and kept at a temperature of $4{ }^{\circ} \mathrm{C}$, in opaque glass flasks, hermetically closed to preserve them from air, light and variations of temperature which are major degradation agents.

\subsection{Phytochemical screening}

in order to highlight the different families of secondary metabolites present in the extracts of studied plants (decocted, infused and macerated), the main way of putting these compounds was the phytochemical screening which focused either on the formation of a colored complex using color reactions, or on the formation of insoluble complexes using precipitation reactions. to achieve this characterization we have followed the experimental protocols of ${ }^{9,10}$. 


\subsection{Chromatographic analysis of Pistacia atlantica Desf. essential oil}

Chromatographic analysis of essential oils was performed at CNRST Rabat using a THERMO ELECTRON Trace MS system (THERMO ELECTRON: Trace Ultra GC; Polaris Q MS) gas chromatograph. The fragmentation is effected by electron impact intensity of $70 \mathrm{eV}$. The capillary column is DB-5 MS (5\% phenyl-methyl-siloxane) $(30 \mathrm{~m} \times 0.25 \mathrm{~mm}$, film thickness: $0.25 \mu \mathrm{m})$. The temperature of the column increases from 50 to $200^{\circ} \mathrm{C}$. at a rate of $4^{\circ} \mathrm{C} . / \mathrm{min}$. Helium is used as a carrier gas with a flow rate of $1.5 \mathrm{ml} / \mathrm{min}$. The injection is made in split mode (leak report: $1 / 70$ ). The listed masses fall in the range of 30 to $500 \mathrm{~m} / \mathrm{z}$. The apparatus is connected to a computer system managing a library of NIST 98 mass spectra.

A standard hydrocarbon (C7-C40) is injected under the same conditions as the essential oils in order to calculate retention indices (Kovats index) ${ }^{11}$ necessary for the identification of the essential oil compounds.

After receiving the spectra (chromatography and spectrometry), the essential oil compounds are identified by comparing the calculated retention indices for each of the eluted compounds (on the basis of the retention times of a hydrocarbon standard
(C7-C40) with those contained in the available databases: Adams, $2007^{12}$ and the National Institute of Standards and Technology (NIST) The mass spectra of each of the compounds are also compared with those of the previously cited databases.

\section{Results and discussions}

\subsection{Yields of Pistacia atlantica Desf. essential oils} Hydrodistilation of leaves of Atlas Pistachio permitted us to obtain an essential oil with a yield of $0.71 \%$ for infected leaves and $0.11 \%$ for healthy ones. Some works in differents Algerian localities, about male and female leaves with galls, show the values of the yield $(0.08-1.89){ }^{13}$ and $(0.46 \%-0.53 \%){ }^{14}$. Others authors reported that the yield for male leaves were $(0.02-0.12 \%)^{15}$, and $(0.08-0.17 \%)$ for different samples leaves ${ }^{16}$.

So, our results are almost compatible in terms of values with those research; Face to a predator or a parasite attacks, the plant reacts by increasing its secondary metabolites production.

3.2. Phytochemical screening of infected and healthy leaves of Pistacia atlantica Desf.

Table 1. Phytochemical screening of infected and healthy leaves of Pistacia atlantica Desf.

\begin{tabular}{|c|c|c|}
\hline & Healthy leaves & Infected leaves by FR \\
\hline Tannins & ++ & +++ \\
\hline Gallic tannins & + & + \\
\hline Catechic tannins & + & + \\
\hline Alkaloids & 0 & 0 \\
\hline Flavone compounds: & + & + \\
Flavones & 0 & + \\
Anthocyanes & + & + \\
\hline Genins & + & + \\
\hline Leucoanthocyanes & + & + \\
\hline Oses and holosides & + & ++ \\
\hline Reducing compounds & + & 0 \\
\hline Mucilages & + & \\
\hline Free anthracene & 0 & + \\
\hline Combined Anthracene & & + \\
\hline C- heterosides & + & 0 \\
\hline O- heterosides & + & \\
\hline Saponosides & 0 & + \\
\hline
\end{tabular}

+++ : Very positive reaction; + + : Moderately positive reaction; + : lowly positive reaction; 0 : Total absence

According to the Table 1 we have detected the presence of some biologically active chemical groups such as tannins, flavonoids, sterols and tri terpenes, the two types of leaves of Pistacia atlantica are rich in tannins and flavonoids.

On the other hand, we noticed that leaves infected by
Forda riccobonii are richer in tannins than healthy ones, this difference in the content of individual phenolic compounds is frequently correlated with a resistance level of plants to infection ${ }^{17}$. So, the therapeutic power of tannins producing species would correlate with their content of metabolites, especially 
with their high content of tannins ${ }^{18}$. It was reported also that hydrolysable tannins from crude drugs showed a strong inhibitory effect against Glucan Synthesis by Glucosyltransferase from Streptococcus mutans causal agent of tooth caries ${ }^{19}$.

We have also detected that infected leaves contain more mucilages, the therapeutic value of this compounds has been extended to wound healing, diabetes, immunostimulation, cancer, angiotensinconverting enzyme inhibition, stomachic, and antioxidant properties, mucilages have been proposed to be one of the most useful materials to modulate drug delivery ${ }^{20}$. Also, the infected leaves and their richness in tannins and mucilages increase their medicinal potency compared to healthy ones.

\subsection{Chemical composition of infected and healthy leaves of Pistacia atlantica Desf. essential oil}

The essential oil analysis results of healthy and infected leaves of Pistacia atlantica Desf. Are presented on the chromatogram below (Figure 3 and 4).

Table 2 shows the identification of 54 compounds for infected leaves and 83 compounds for healthy ones representing respectively $99.29 \%$ and $98.69 \%$ of the chemical composition.

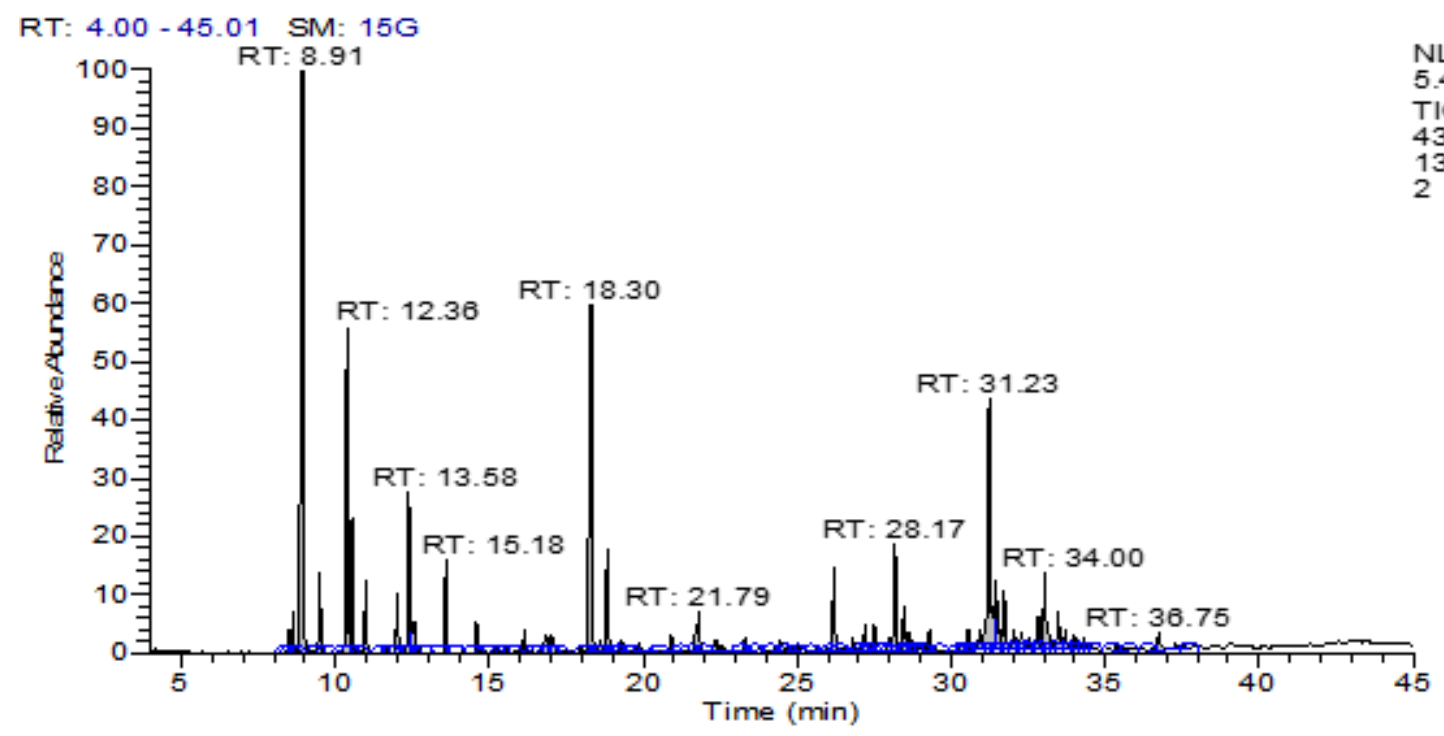

Figure 3. Essential oil chromatogram from the infected leaves by galls of Pistacia atlantica Desf.

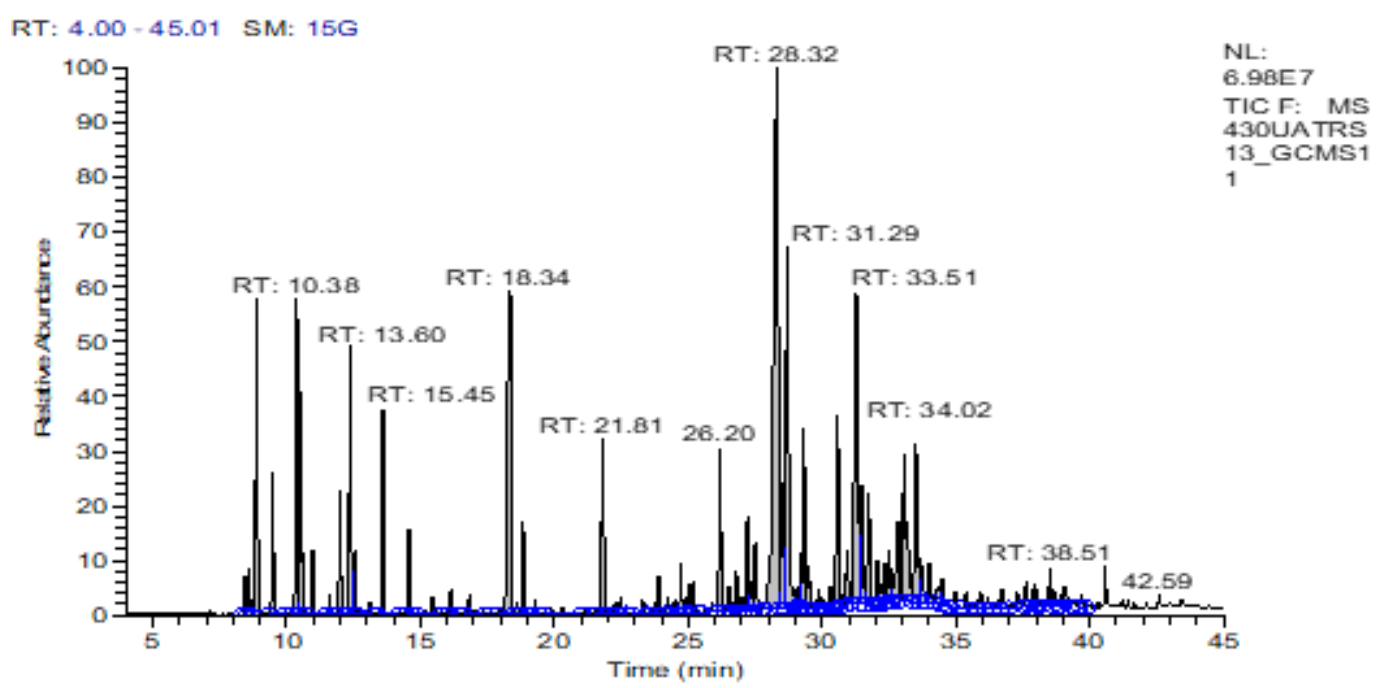

Figure 4. Essential oil chromatogram from the healthy leaves of Pistacia atlantica Desf. 
Table 2. Chemical Composition of the essential oil of infected and healthy leaves of Pistacia atlantica Desf.

\begin{tabular}{|c|c|c|c|c|c|}
\hline Compound & $\begin{array}{c}\mathrm{IK} \\
\text { (Adams) }\end{array}$ & $\begin{array}{l}\text { Weight } \\
\text { molecular }\end{array}$ & brute Formula & $\begin{array}{c}\text { Area }(\%) \text { of } \\
\text { infected leaves }\end{array}$ & $\begin{array}{c}\text { Area }(\%) \\
\text { of healthy } \\
\text { leaves }\end{array}$ \\
\hline Tricyclene & 926 & 136 & C10 H16 & 0.47 & 0.38 \\
\hline$\alpha$-Thujene & 930 & 136 & $\mathrm{C} 10 \mathrm{H} 16$ & 0.89 & 0.44 \\
\hline$\alpha$-Pinene & 939 & 136 & C10 H16 & 19.76 & 3.70 \\
\hline Camphene & 954 & 136 & C10 H16 & 1.67 & 1.39 \\
\hline Sabinene & 975 & 136 & C10 H16 & 7.63 & 3.81 \\
\hline$\beta$-Pinene & 979 & 136 & C10 H16 & 2.87 & 2.31 \\
\hline Myrcene & 990 & 136 & C10 H16 & 1.56 & 0.66 \\
\hline$\alpha$-Phellandrene & 1002 & 136 & C10 H16 & 0.20 & 0.20 \\
\hline$\alpha$-Terpinene & 1017 & 136 & C10 H16 & 1.27 & 1.23 \\
\hline$\rho$-Cymene & 1024 & 134 & $\mathrm{C} 10 \mathrm{H} 14$ & 3.51 & 3.47 \\
\hline$\beta$-Phellandrene & 1029 & 136 & $\mathrm{C} 10 \mathrm{H} 16$ & 1.28 & 0.62 \\
\hline (Z)- $\beta$-Ocimene & 1037 & 136 & C10 H16 & - & 0.20 \\
\hline (E)- $\beta$-Ocimene & 1050 & 136 & C10 H16 & 2.00 & 2.22 \\
\hline$\gamma$-Terpinene & 1059 & 136 & C10 H16 & - & 0.89 \\
\hline cis-Sabinene hydrate & 1070 & 154 & C10 H18 O & 0.70 & 0.27 \\
\hline cis-Linalool oxide & 1072 & 170 & $\mathrm{C} 10 \mathrm{H} 18 \mathrm{O} 2$ & 0.29 & - \\
\hline trans-Sabinene hydrate & 1098 & 154 & C10 H18 O & 0.62 & 0.45 \\
\hline$\alpha$-Pinene oxide & 1099 & 152 & $\mathrm{C} 10 \mathrm{H} 16 \mathrm{O}$ & 0.39 & - \\
\hline 1-Undecyne & 1125 & 152 & C11 H20 & - & 0.31 \\
\hline$\alpha$-Campholenal & 1126 & 152 & C10 H16 O & 0.40 & - \\
\hline Terpinen-4-ol & 1177 & 154 & C10 H18 O & 11.94 & 7.17 \\
\hline$\rho$-Cymen-8-ol & 1182 & 150 & $\mathrm{C} 10 \mathrm{H} 14 \mathrm{O}$ & 0.35 & 0.17 \\
\hline$\alpha$-Terpineol & 1188 & 154 & $\mathrm{C} 10 \mathrm{H} 18 \mathrm{O}$ & 2.47 & 1.08 \\
\hline cis-Piperitol & 1196 & 154 & C10 H18 O & 0.30 & 0.17 \\
\hline cis-Carveol & 1229 & 152 & C10 H16 O & - & 0.34 \\
\hline trans-Piperitone epoxide & 1256 & 168 & C10 H16 O & 0.86 & - \\
\hline 2-Ethyl menthone & 1282 & 182 & $\mathrm{C} 12 \mathrm{H} 22 \mathrm{O}$ & 0.44 & 0.28 \\
\hline Isobornyl acetate & 1285 & 196 & $\mathrm{C} 12 \mathrm{H} 20 \mathrm{O} 2$ & 1.55 & 2.44 \\
\hline Thymol & 1290 & 150 & $\mathrm{C} 10 \mathrm{H} 14 \mathrm{O}$ & - & 0.11 \\
\hline trans-Verbenyl acetate & 1292 & 194 & $\mathrm{C} 12 \mathrm{H} 18 \mathrm{O} 2$ & 0.84 & 0.14 \\
\hline Carvacrol & 1299 & 150 & $\mathrm{C} 10 \mathrm{H} 14 \mathrm{O}$ & - & 0.24 \\
\hline Undec-(9E)-en-1-al & 1312 & 168 & $\mathrm{C} 11 \mathrm{H} 20 \mathrm{O}$ & 0.49 & - \\
\hline neoiso-Isopulegyl acetate & 1313 & 196 & C10 H16 & - & 0.45 \\
\hline$\alpha$-Cubebene & 1351 & 204 & $\mathrm{C} 15 \mathrm{H} 24$ & - & 0.12 \\
\hline $\begin{array}{l}\text { 1,2-dihydro-1,1,6- } \\
\text { trimethylnaphthalene }\end{array}$ & 1355 & 172 & C13 H16 & - & 0.18 \\
\hline$\alpha$-Copaene & 1376 & 204 & $\mathrm{C} 15 \mathrm{H} 24$ & 0.40 & 0.75 \\
\hline$\beta$-Bourbonene & 1388 & 204 & $\mathrm{C} 15 \mathrm{H} 24$ & - & 0.33 \\
\hline$\beta$-Elemene & 1390 & 204 & $\mathrm{C} 15 \mathrm{H} 24$ & - & 0.55 \\
\hline (Z)-Caryophyllene & 1408 & 204 & $\mathrm{C} 15 \mathrm{H} 24$ & 1.93 & - \\
\hline$\alpha$-Gurjunene & 1409 & 204 & $\mathrm{C} 15 \mathrm{H} 24$ & - & 0.22 \\
\hline (E)-Caryophyllene & 1419 & 204 & $\mathrm{C} 15 \mathrm{H} 24$ & - & 1.93 \\
\hline$\beta$-Copaene & 1432 & 204 & $\mathrm{C} 15 \mathrm{H} 24$ & - & 0.37 \\
\hline$\gamma$-Elemene & 1436 & 204 & $\mathrm{C} 15 \mathrm{H} 24$ & 0.61 & - \\
\hline$\beta$-Humulene & 1438 & 204 & $\mathrm{C} 15 \mathrm{H} 24$ & 0.23 & 0.35 \\
\hline Aromadendrene & 1441 & 204 & $\mathrm{C} 15 \mathrm{H} 24$ & 0.61 & 0.11 \\
\hline$\alpha$-neo-Clovene & 1454 & 204 & $\mathrm{C} 15 \mathrm{H} 24$ & 0.67 & 0.91 \\
\hline allo-Aromadendrene & 1460 & 204 & $\mathrm{C} 15 \mathrm{H} 24$ & - & 0.47 \\
\hline cis-Cadina-1(6),4-diene & 1463 & 204 & $\mathrm{C} 15 \mathrm{H} 24$ & 0.30 & - \\
\hline Ishwarane & 1466 & 204 & $\mathrm{C} 15 \mathrm{H} 24$ & - & 0.19 \\
\hline cis-Muurola-4(14),5-diene & 1466 & 204 & $\mathrm{C} 15 \mathrm{H} 24$ & 2.77 & - \\
\hline 4,5-di-epi-Aristolochene & 1473 & 204 & $\mathrm{C} 15 \mathrm{H} 24$ & 1.15 & - \\
\hline$\gamma$-Gurjunene & 1477 & 204 & $\mathrm{C} 15 \mathrm{H} 24$ & - & 1.23 \\
\hline Widdra-2,4(14)-diene & 1482 & 204 & $\mathrm{C} 15 \mathrm{H} 24$ & 0.73 & - \\
\hline$\alpha$-Amorphene & 1484 & 204 & $\mathrm{C} 15 \mathrm{H} 24$ & - & 15.05 \\
\hline
\end{tabular}




\begin{tabular}{|c|c|c|c|c|c|}
\hline Viridiflorene & 1496 & 204 & $\mathrm{C} 15 \mathrm{H} 24$ & - & 1.69 \\
\hline$\alpha$-Muurolene & 1500 & 204 & C15 H24 & - & 6.20 \\
\hline Cuparene & 1504 & 202 & $\mathrm{C} 15 \mathrm{H} 22$ & 0.27 & - \\
\hline Germacrene A & 1509 & 204 & $\mathrm{C} 15 \mathrm{H} 24$ & - & 0.20 \\
\hline$\alpha$-Bulnesene & 1509 & 204 & $\mathrm{C} 15 \mathrm{H} 24$ & 0.75 & - \\
\hline$\delta$-Amorphene & 1512 & 204 & $\mathrm{C} 15 \mathrm{H} 24$ & - & 0.56 \\
\hline$\gamma$-Cadinene & 1513 & 204 & $\mathrm{C} 15 \mathrm{H} 24$ & 0.80 & 2.07 \\
\hline trans-Cycloisolongifol-5-ol & 1513 & 220 & $\mathrm{C} 15 \mathrm{H} 24 \mathrm{O}$ & - & 0.58 \\
\hline 7-epi- $\alpha$-Selinene & 1522 & 204 & C15 H24 & - & 0.11 \\
\hline trans-Cadina-1,4-diene & 1534 & 204 & $\mathrm{C} 15 \mathrm{H} 24$ & - & 0.22 \\
\hline$\alpha$-Cadinene & 1538 & 204 & C15 H24 & - & 0.09 \\
\hline$\alpha$-Calacorene & 1545 & 204 & C15 H20 & - & 0.09 \\
\hline Hedycaryol & 1548 & 222 & $\mathrm{C} 15 \mathrm{H} 26 \mathrm{O}$ & - & 0.34 \\
\hline Elemol & 1549 & 222 & $\mathrm{C} 15 \mathrm{H} 26 \mathrm{O}$ & - & 2.67 \\
\hline trans-Dauca-4(11),7-diene & 1557 & 204 & C15 H24 & - & 0.13 \\
\hline Germacrene B & 1561 & 204 & $\mathrm{C} 15 \mathrm{H} 24$ & 0.56 & 0.76 \\
\hline Maaliol & 1567 & 222 & $\mathrm{C} 15 \mathrm{H} 26 \mathrm{O}$ & 2.15 & 1.68 \\
\hline Spathulenol & 1578 & 220 & $\mathrm{C} 15 \mathrm{H} 24 \mathrm{O}$ & 8.90 & 6.46 \\
\hline Globulol & 1590 & 222 & $\mathrm{C} 15 \mathrm{H} 26 \mathrm{O}$ & 1.91 & 1.83 \\
\hline Cubeban-11-ol & 1595 & 222 & $\mathrm{C} 15 \mathrm{H} 26 \mathrm{O}$ & 0.52 & 0.63 \\
\hline cis-dihydro-Mayurone & 1595 & 206 & $\mathrm{C} 14 \mathrm{H} 22 \mathrm{O}$ & - & 0.29 \\
\hline$\beta$-Biotol & 1613 & 220 & $\mathrm{C} 15 \mathrm{H} 24 \mathrm{O}$ & - & 0.50 \\
\hline 1-epi-Cubenol & 1628 & 222 & $\mathrm{C} 15 \mathrm{H} 26 \mathrm{O}$ & 0.69 & - \\
\hline epi- $\alpha$-Muurolol & 1642 & 222 & $\mathrm{C} 15 \mathrm{H} 26 \mathrm{O}$ & 0.38 & 0.72 \\
\hline Selina-3,11-dien-6- $\alpha$-ol & 1644 & 220 & $\mathrm{C} 15 \mathrm{H} 24 \mathrm{O}$ & 0.87 & - \\
\hline$\alpha$-Cadinol & 1654 & 222 & $\mathrm{C} 15 \mathrm{H} 26 \mathrm{O}$ & 1.23 & - \\
\hline Valerianol & 1658 & 222 & $\mathrm{C} 15 \mathrm{H} 26 \mathrm{O}$ & - & 1.80 \\
\hline $\begin{array}{l}\text { 14-hydroxy-9-epi-(E)- } \\
\text { Caryophyllene }\end{array}$ & 1669 & 220 & $\mathrm{C} 15 \mathrm{H} 24 \mathrm{O}$ & 0.54 & 0.53 \\
\hline Eudesm-7(11)-en-4-ol & 1700 & 222 & $\mathrm{C} 15 \mathrm{H} 26 \mathrm{O}$ & - & 2.64 \\
\hline Nootkatol & 1715 & 220 & $\mathrm{C} 15 \mathrm{H} 24 \mathrm{O}$ & 2.54 & 3.35 \\
\hline (E)-Nuciferal & 1728 & 216 & $\mathrm{C} 15 \mathrm{H} 20 \mathrm{O}$ & 0.43 & 0.68 \\
\hline Khusimol & 1742 & 220 & $\mathrm{C} 15 \mathrm{H} 24 \mathrm{O}$ & - & 0.36 \\
\hline$\beta$-(Z)-Curcumen-12-ol & 1756 & 220 & $\mathrm{C} 15 \mathrm{H} 24 \mathrm{O}$ & - & 0.36 \\
\hline $\begin{array}{l}\text { 7,14-anhydro-Amorpha-4,9- } \\
\text { diene }\end{array}$ & 1756 & 218 & $\mathrm{C} 15 \mathrm{H} 22 \mathrm{O}$ & - & 0.25 \\
\hline Ambroxide & 1757 & 236 & C16 H28 O & 0.55 & - \\
\hline 8- $\alpha$-11-Elemodiol & 1747 & 238 & $\mathrm{C} 15 \mathrm{H} 26 \mathrm{O} 2$ & 0.34 & 0.35 \\
\hline Benzyl benzoate & 1760 & 212 & C14 H12 O2 & 1.08 & - \\
\hline (E)- $\alpha$-Atlantone & 1778 & 218 & $\mathrm{C} 15 \mathrm{H} 22 \mathrm{O}$ & - & 0.10 \\
\hline (Z)- $\alpha$-Santalol acetate & 1778 & 262 & $\mathrm{C} 17 \mathrm{H} 26 \mathrm{O} 2$ & - & 0.32 \\
\hline 14-hydroxy- $\alpha$-Muurolene & 1780 & 220 & C15 H24 O & - & 0.22 \\
\hline 7-acetoxy-Elema-1,3-dien-8-ol & 1786 & 280 & $\mathrm{C} 17 \mathrm{H} 28 \mathrm{O} 3$ & - & 0.19 \\
\hline 14-hydroxy- $\delta$-Cadinene & 1803 & 220 & C15 H24 O & - & 0.35 \\
\hline Eudesm-11-en-4- $\alpha, 6$ - $\alpha$-diol & 1808 & 238 & $\mathrm{C} 15 \mathrm{H} 26 \mathrm{O} 2$ & - & 0.29 \\
\hline 2-Butyl chromone & 1816 & 202 & $\mathrm{C} 13 \mathrm{H} 14 \mathrm{O} 2$ & - & 0.30 \\
\hline$\alpha$-Chenopodiol & 1856 & 238 & $\mathrm{C} 15 \mathrm{H} 26 \mathrm{O} 2$ & - & 0.51 \\
\hline Cubitene & 1878 & 272 & C20 H32 & - & 0.26 \\
\hline$\beta$-Chenopodiol-6-acetate & 1890 & 280 & $\mathrm{C} 17 \mathrm{H} 28 \mathrm{O}$ & - & 0.11 \\
\hline
\end{tabular}

Total (infected leaves) : 99.29\% Monoterpenes

Hydrocarbon : $43.31 \%$

Oxygenated : $18.32 \%$

Sesquiterpenes

Hydrocarbon : $12.21 \%$

Oxygenated : $20.50 \%$
Total (healthy leaves) : $98.69 \%$ Monoterpenes

Hydrocarbon : $21.97 \%$

Oxygenated : $10 \%$

Sesquiterpenes

Hydrocarbon : $\mathbf{3 4 . 7 0} \%$

Oxygenated : $27.20 \%$ 
It should be noted that for infected leaves, the hydrocarbon monoterpenes represent $43.31 \%$ followed by oxygenated monoterpenes $18.32 \%$ whereas the sesquiterpenes represent $32.71 \%$ of the total composition of the essential oil ; it is the opposite case concerning the healthy leaves which represent for the hydrocarbonated sesquiterpenes $34.70 \%$ followed by oxygenated sesquiterpenes $27.20 \%$ whereas for monoterpenes represents $31.97 \%$.

The chemical profile of infected leaves of Atlas Pistachio is predominated by $\alpha$-Pinene $(19.76 \%)$ followed by Terpinen-4-ol, Spathulenol and Sabinene with percentages of $11.94 \%, 8.90 \%$ and $7.63 \%$, respectively. Healthy leaves are predominated by $\alpha$ Amorphene (15.05\%) followed by Terpinen-4-ol, Spathulenol and $\alpha$-Muurolene with percentages of $7.17 \%, 6.46 \%$ and $6.20 \%$, respectively.

Several works have been devoted to chemical composition study of $P$. atlantica essential oils: The essential oils of the leaves have been studied by ${ }^{21,22,}$ 16,15 , and the galls by $16,14,13$.

Essential oils from leaves and galls of $P$. atlantica, analyzed by GC/FID, GC/MS and 13C-NMR, are dominated by monoterpene hydrocarbons, $\alpha$-pinene $(32.6-54.7 \%)$ and $\beta$-pinene $(8.0-20.2 \%)$ being the major components. Sesquiterpenes accounted for $14.1-21.7 \%$ in leaf oils and $4.8 \%$ in gall oil ${ }^{16}$.

Concerning healthy leaves, oxygenated monoterpenes and sesquiterpenes predominated in the essential oil of Pistacia atlantica Desf. collected in July 2000 from Marrakesh region, of which terpinene-4-ol (21.7\%) and elemol (20.0\%) were the most abundant components ${ }^{21}$.

The Atlas Pistachio from Greek East Aegean islands (Kalimnos and Lesvos) collected during 2002 have myrcene $(17.8 \%, 24.8 \%)$ and terpinen-4-ol $(11.6 \%$, $6.0 \%)$ in the essential oil from the female plants. In the Kalimnos and Lesvos samples, respectively, while in the leaf oil from the male plants terpinen-4-ol $(17.3 \%$ Kalimnos) and p-mentha-1(7),8-diene (41.1\%, Lesvos) were the dominant constituents ${ }^{22}$.

The essential oil of leaves collected from Male trees of Pistacia atlantica Desf. (34 samples) Randomly from four different locations in Algeria are rich in monoterpenes and oxygenated sesquiterpenes. Fortyseven compounds were identified; the main compounds were not the same in all analysed samples. The percentages ranges of the major components identified from the different locations were $\alpha$-pinene $+\alpha$-thujene (5.54-66.61\%), camphene (0.75$20.85 \%)$, $\beta$-pinene $(1.09-13.12 \%)$, p-cymene $(0.39$ $10.19 \%)$, terpinen-4,ol $(0.42-15.97 \%) \quad$ and spathulenol $(0.46-32.64 \%)^{15}$.

In the present work spathulenol and terpinen-4-ol found in healthy leaves as a secondary and tertiary compound are also present in other plants from different locations, it is the first time that $\boldsymbol{\alpha}$ Amorphene chemotype is revealed. Concerning infected leaves, the essential oils (EOs) of unripe galls (from male and female plants) of a total number of 52 samples of Pistacia atlantica collected from different regions in Algeria were analysed by GC/MS and GC. The results of both methods of principal component analysis and hierarchical ascendant classification revealed the presence of two different chemotypes: $\alpha$ pinene chemotype and $\alpha$-pinene/sabinene/ terpinen-4ol chemotype ${ }^{13}$.

The essential oils obtained by hydrodistillation of unripe galls of Pistacia atlantica and collected from both male and female trees from Algeria showing the occurrence of a new 3-Carene rich chemotype showing content of $75.34 \%$. The second chemotype was $\alpha$-pinene/ $\beta$-pinene, which is rich in $\alpha$-pinene $(59.01 \%)$ and $\beta$-pinene $(13.26 \%){ }^{14}$. Also, $\alpha$ pinene/sabinene/ terpinen-4-ol chemotypes were found by these researchers; this is in agreement with our results, especially for $\boldsymbol{\alpha}$-pinene as a first major compound. Also, we must notice a new 3-Carene found by Gourine in Algeria.

So we observe that infected leaves contain more monoterpenes hydrocarbon responsible for various pharmacological properties including antifungal, antibacterial, antioxidant, anticancer, antispasmodic, hypotensive, and vasorelaxant ${ }^{23}$. The significant volatile constituent $\alpha$-pinene present in our infected leaves has interesting antibacterial properties on various bacterial strains ${ }^{24}$.

Hence, it appears that the profile of the Pistacia essential oils varies depending on leaves health, the gender of the tree, geographical area, and the harvest period. These differences in the chemical composition are generally responsible for the diversity of medicinal uses, which differs from tradition to tradition and from country to another.

This study gives a better idea about volatile compounds contained in the infected and healthy leaves of $P$. atlantica, which grows in Morocco and plays an important role in the daily life populations (fodder for livestock, wood for the industry, medicinal uses). Also, the difference between the two types of leaves allows us to conclude that the attack of plants by a predator or a parasite modifies its chemical composition and could let to the appearance of new chemotypes.

\section{Conclusion}

The work we did led us to conclude that essential oils of leaves with galls differ in yield and composition in comparison with healthy ones; so, Pistacia atlantica Desf. responds to the aphids aggression by increasing essential oil production; also, there was a difference between chemical composition as infected leaves were predominated by $\alpha$-Pinene for and instead of $\alpha$-Amorphene observed in healthy leaves. Moreover, infected leaves reduce their total number of compounds but increase the monoterpenes hydrocarbon class, which contains new molecules 
useful in industrial and pharmaceutical domains.

\section{References}

1- M . Fennane, M. Ibn-Tattou, Flore pratique du Maroc, Vol. 2, Angiospermae (LeguminosaeLentibulariaceae): Inst. Scientifique, 2007, 636p.

2- A. Benabid, M. Fennane, Connaissances sur la végétation du Maroc phytogéographie, phytosociologie et séries de végétation, 1994, Lazaroa 14.

3- A. Benabid, Flore et écosystèmes du Maroc, évaluation et conservation de la biodiversité, Ed.Ibis Press, 2000, 359pp.

4- R. Álvarez, A. Encina, \& N. Hidalgo Pérez, Histological aspects of three Pistacia terebinthus galls induced by three different aphids: Paracletus cimiciformis, Forda marginata and Forda formicaria, Plant Science, 2009, 176(2), 303-314.

5- E. Charabot, C.L. Gatin, Le parfum chez la plante, Gaston Doin, 1908, 404p.

6- D. Zabaras, R.N. Spooner-Hart, S.G. Wyllie, Effects of mechanical wounding on concentration and composition of essential oil from Melaleuca alternifolia leaves, Biochemical systematics and ecology, 2002, 30: 399-412.

7- H. Benhssaini, M. Belkhoja, Le pistachier de l'Atlas en Algérie entre la survie et disparition, La feuille et l'aiguille, 2004, 54, 1-2.

8- A. Yaaqobi, L. El hafid \& B. Haloui, Etude biologique de "Pistacia atlantica Desf de la région orientale du Maroc, Biomatec Echo, 2009, Volume $3, \mathrm{~N}^{\circ} 6$, pp. $39-49$.

9- H. Benmehdi, O. Hasnaoui, O. Benali, F. Salhi, Phytochemical investigation of leaves and fruits extracts of Chamaerops humilis L. J. Mater. Environ, 2012, Sci 3, 320-327.

10-D. Dah-nouvlessounon, H. Adoukonou-sagbadja, N. Diarrassouba, H. Sina, A. Adjanohoun, M. Inoussa, D. Akakpo, J.D. Gbenou, S.O. Kotchoni, M. H. Dicko, L. Baba-moussa, Phytochemical analysis and biological activities of Cola nitida Bark, Biochem, 2015, Res. Int. 12. hindawi Publ. Coporation.

11-E. Kovàts, Adv. Chromatogr., 1965, 1, 229-247.

12-R.P. Adams, Identification of Essential Oils Components by Gas Chromatography/Quadrupole Mass Spectroscopy (Allured, Carol Stream), 2007.

13-I. Sifi, N. Gourine, E. M. Gaydou \& M. Yousfi, Chemotypes of essential oil of unripe galls of Pistacia atlantica Desf. from Algeria, Nat Prod Res, 2015, 29(20), 1945-1949.
14-N. Gourine, I. Sifi, M. E. Gaydou \& M. Yousfi, Chemical composition of the essential oil of unripe galls of Pistacia atlantica Desf. from Algeria, The Natural Products Journal, 2011, 1(2), 125-127.

15-N. Gourine, M. Yousfi, I. Bombarda, B. Nadjemi, P. Stocker \& E.M. Gaydou, Antioxidant activities and chemical composition of essential oil of Pistacia atlantica from Algeria, Industrial Crops Products, 2010, 31, 203-208.

16-S. Mecherara-Idjeri, A. Hassani, V. Castola \& J. Casanova, Composition of leaf, fruit and gall essential oils of Algerian Pistacia atlantica Desf., J. Essent. Oil Res., 2008, 20(3), 215-219.

17-A. Clérivet, I. Alami, F. Breton, D. Garcia, \& C. Sanier, Les composés phénoliques et la résistance des plantes aux agents pathogènes, Acta botanica gallica, 1996, 143(6), 531-538.

18-A. Sereme, J. Milogo-Rasolodimby, S. Guinko, \& M. Nacro, Propriétés therapeutiques des plantes a tanins du Burkina Faso, Pharmacopée et médecine traditionnelle africaine, 2011, 15.

19-N. Kakiuchi, M. Hattori, M. Nishizawa, T. Yamagushi, T. Okuda, \& T. Namba, Studies on Dental Caries Prevention by Traditional Medicines. VIII.: Inhibitory Effect of Various Tannins on Glucan Synthesis by Glucosyltransferase from Streptococcus mutans, Chemical and pharmaceutical bulletin, 1986, 34(2), 720-725.

20-J. Wadhwa, A. Nair, \& R. Kumria, Potential of plant mucilages in pharmaceuticals and therapy, Current drug delivery, 2013, 10(2), 198-207.

21-A. F. Barrero, M. M. Herrador, J. F. Arteaga, M. Akssira, F. Mellouki, A. Belgarrabe \& M. A. Blazquez, Chemical Composition of the Essential Oils of Pistacia atlantica Desf. J., Essent. Oil Res., 2005, 17(1), 52-54.

22-O. Tzakou, I. Bazos \& A. Yannitsaros, Volatile metabolites of Pistacia atlantica Desf. from Greece, Flavour and fragrance journal, 2007, 22(5), 358- 362.

23-M. R. Santos, F. V. Moreira, B. P. Fraga, D. P. D. Souza, L. R. Bonjardim, \& L. J. Quintans-Junior, Cardiovascular effects of monoterpenes, a review. Revista Brasileira de Farmacognosia, 2011, 21(4), 764-771.

24-C . Carson, T. Riley, Antimicrobial activity of the major components of the essential oil of Melaleuca alternifolia, Journal of Applied Microbiology, 1995, 78: 264-269. 